\author{
TAKESHI IIDA
}

\title{
Media Coverage and the Association between Japanese Perceptions of South Korea and North Korea
}

Changing public attitudes toward foreign countries has long been of interest to scholars and policymakers. This study focuses on how media coverage led to the general public associating two countries more closely with each other. Analyzing monthly public opinion data from 1988 to 2010, this study finds that negative Japanese attitudes toward North Korea are more strongly associated with those toward South Korea when South Korea appears more frequently in newspaper articles on North Korea. This suggests that the media play a significant role in influencing the extent to which citizens tend to group countries together.

KEYWORDS: Japanese public opinion, South Korea, North Korea, media effects

Takeshi IIDA is an Associate Professor of Political Science at Doshisha University. 
ChANGING PUBLIC attitudes toward foreign countries has long been of interest to scholars and policymakers. A large volume of the literature has argued that the way in which citizens view foreign policy affairs varies across states, and changes over time within a state, leading to a substantial change in foreign and security policies in democracies (e.g., BAUM and Potter 2015; Jacobs and Page 2005; Hartley and Russett 1992).

Previous studies, as will be shown later in this paper, have suggested that economic, military, and cultural ties to a foreign country, as well as information about foreign countries, are key to understanding citizen attitudes toward that country. However, we know little about the way they perceive linkages between foreign countries, and the role the media plays in helping form these perceptions. Therefore, this study focuses on the effect of media coverage in creating an association between two countries in the public perception, arguing that as the media increasingly links two countries in their coverage, public attitudes more strongly associate these countries with each other. When forming their attitudes toward a foreign country, their perceptions of associated countries, which they group together in terms of culture, language, and ethnicity, are taken into account. Therefore, a change in attitude toward one country is associated with a change toward another country in the same country group. Moreover, such perceptional ties are strengthened when the two countries are reported in the same context by the media.

Examining changes in Japanese attitudes toward South and North Korea provides a good opportunity to test this theory because these two countries have a shared culture, language, and ethnicity, thus allowing us to highlight the media effect. A time-series analysis of monthly public opinion data shows that negative Japanese attitudes toward North Korea are more strongly associated with those toward South Korea when South Korea appears more frequently in newspaper articles on North Korea. This indicates that the media plays a significant role in influencing the extent to which citizens group foreign countries.

\section{Research Question}

Public opinion changes over time according to domestic and international factors, and has been found to influence foreign and security policy processes (e.g., Baum and Potter 2015; Jacobs and Page 2005; Hartley and RuSSETT 1992), especially under circumstances where a multi-party system with a free press provides citizens with the tools to criticize government (BAum and PotTer 2015). Public opinion can set the range of 
alternatives on which political leaders can agree in international negotiations (PutNam 1988), and can also tie a government's hands when forming a security policy (IzUmikawa 2010). The significance of public opinion in foreign policy decisions has led both scholars and policymakers to question why public attitudes toward foreign countries change over time.

Public attitudes toward foreign countries may have a particularly significant and direct effect on government foreign policies because public negativity toward a foreign country can result in demands for elected officials to take an uncompromising stance against a country. Previous studies have offered mainly two explanations for the variation in public attitudes toward foreign countries at the state level. A number of scholars attribute this to changes in a bilateral relationship with a foreign country, in terms of the balance of military capability and security ties (MEARSHEIMER 1990), economic interdependence (RUSSETT and ONEAL 2001), import dependence (WALLERSTEIN 2002), cultural affinity (HuNTINGTON 1993), foreign policy behaviors (FURIA and LUCAS 2006), foreign aid (GOLDSMITH and HorIUCHI 2012), and domestic ideological opposition (MIYAKe 2001). ${ }^{1}$

Others consider media coverage as a determinant of the variation in public attitudes toward foreign countries. Information about foreign countries garnered through the domestic media matters in public opinion formation (HAYES and GUARDINO 2012). It is not only the information that citizens receive, but also the frames in which this information is presented that shapes public opinion (GLAZIER and Boydstun 2012). In the same way, public attitudes toward foreign countries are influenced by exposure to information about foreign countries (PERRY 1987; 1990; FukUMOTO and FURUTA 2012) and the way in which information about foreign countries is framed (DELL'ORTo et al. 2004).

As noted above, while economic, military, and cultural ties to a foreign country and the provision of foreign information have been shown as vital to understanding public attitudes toward foreign countries, previous studies have failed to consider convergent perceptions of foreign countries resulting from media influence. If citizens perceive certain foreign countries as a group, their attitudes toward these countries should be associated with one other. In fact, SALA, SCOTT, and SPRIGGS II (2007) have shown that

1. While these previous studies (and this study) address variations in public attitudes toward foreign countries, there is a larger volume of literature that attributes individual attitudes toward foreigners and immigrants to such factors as socioeconomic status, personal contacts, and networks (e.g., Chandler and Tsai 2001; MCLARen 2003; HainmuelLER and HISCOX 2007). 
Olympic figure skating judges tended to give similar scores to skaters from countries of the same ideological camp during the Cold War, but the tendency disappeared with the end of the war. This suggests that the notion of group identity matters in evaluating a country.

Previous studies, however, have only shown that exposure to favorable information about a foreign country fosters favorable public attitudes toward that country, but they reveal little about the role of the media in forming the public perception of linkages between countries, leaving unanswered how the public perceives an association between foreign countries, and how media coverage conditions this linkage.

\section{Theory and Hypothesis}

In response to these research questions, and drawing upon semantic network models in cognitive psychology (ANDERSON 1983), this study proposes that as the media link two countries more frequently in their coverage, public attitudes toward them become more strongly associated with each other. According to Lodge and McGraw (1991), advocates of the cognitive psychological approach in political science, knowledge structures in long-term memory are represented as configurations of nodes linked to one another in a network of associations.

Nodes can represent a wide variety of politically relevant objects, including politicians, interest groups, issues, specific events, and countries, and take on the valence of the evaluation (positive or negative) for them. The evaluations are correlated when the nodes are linked to one other. If citizens evaluate two countries whose nodes are linked to each other in their long-term memory, their evaluations will be correlated in the sense that the positive regard for one country will be associated with that of the other. If the nodes are not linked to each other, however, their evaluations of the two countries will be independent of each other.

The strength of a link is a function of the strength between two nodes, and is dependent on the simultaneous activation of the linked nodes. For example, when two countries are both brought into working memory and repeatedly connected, such repetition will strengthen the link between the two countries, but once they are infrequently connected in working memory, the link is dropped from long-term memory.

In the context of the research, this implies that when forming their attitudes toward a foreign country, people consider their perceptions of other countries that they believe are linked in terms of culture, language, and ethnicity. Therefore, a change in attitude toward one country will affect the 
perception of other countries in the same country group. Moreover, such perceptional links will be strengthened or weakened, depending on how often the media report the two countries in the same context.

In other words, let us suppose that citizens toughen their attitudes toward a foreign country in the wake of an event related to the country. They will also feel negative about the other country that is perceived to belong to the same group. The extent to which they do so, however, depends on the strength of a cognitive link between the two countries. When increasing media reports on two countries strengthen an existing link between the two countries in long-term memory, the associations between changes in their attitudes toward the two countries will also be stronger. Conversely, when the declining media reports on the two countries weaken an existing link between two countries in long-term memory, the associations between changes in their attitudes toward the two countries will also be weaker.

It should be noted that there are two assumptions in the theoretical argument described above. First, the link between the two countries is already established, and fairly strong in long-term memory. Second, the media have a short-term (instantaneous) effect on the strength of the link. Scholars have agreed that the media exert both a short-term and a longterm effect on public attitudes (e.g., McQuaIL 2010). This must also be the case for the effect of the media on the association between countries in the public perception, but this study will only focus on the former effect in accordance with the theoretical framework.

\section{JAPANESE ATTITUDES TOWARD SOUTH KOREA AND NORTH KOREA}

Examining Japanese attitudes toward South and North Korea provides a unique opportunity to test this theory for three reasons. First, these two countries have a shared culture, language, and ethnicity, which is consistent with the theoretical framework. Since previous studies have indicated that the linguistic, ethnic, and cultural similarities between countries can be the main source of the correlation in public attitudes toward the countries, Japanese attitudes toward South Korea and North Korea are expected to be highly associated. Therefore, these two countries can assist in highlighting the effect of the media on the convergence of public attitudes toward foreign countries.

Second, as shown in the later section, Japanese attitudes toward South and North Korea exhibit meaningful changes over time. There are possible sources of conflict between Japan and these two countries, including Japan's negative legacy of colonization before the end of World War II, as 
well as the aggressive nature of the authoritarian North Korean regime. Such sources of conflict can cultivate negativity when they become salient as events, and can result in large fluctuations in Japanese attitudes toward the two countries.

Finally, reliable data for Japanese attitudes toward foreign countries are available. Every month since June 1960, the Jiji polls have asked randomly sampled respondents of voting age to choose three countries that they like and three that they dislike from a list of countries. While the list originally had nine countries, including the United States, the Soviet Union (Russia following the collapse of the Soviet Union), the United Kingdom, France, West Germany (Germany following unification), Switzerland, India, China, and South Korea, the number of listed countries has been fixed at ten since North Korea was added in May 1975.

Applied to this case, the theory indicates that Japanese associate South and North Korea with each other because the nodes for these two countries are linked in the long-term memory of the Japanese public based on their linguistic, ethnic, and cultural similarities. Moreover, the association is stronger when one country increasingly appears in news stories that mention the other, as the link is strengthened by repeatedly seeing the countries appearing simultaneously. Therefore, the hypotheses regarding the changes in Japanese attitudes toward South and North Korea can be summarized as follows:

Hypothesis 1: Japanese attitudes toward North Korea are positively associated with those toward South Korea, and vice versa.

Hypothesis 2: As South Korea appears in media reports that mention North Korea more frequently, the association of Japanese attitudes toward North Korea with those toward South Korea increases, and vice versa.

\section{Research Design}

A time-series analysis was conducted to test the hypotheses, using monthly aggregated data ${ }^{2}$ from the Jiji polls conducted between April 1988 and May 2010. ${ }^{3}$ We ran two separate time-series regressions to

2. The sources of monthly aggregated data from the Jiji polls are: Seron Chōsa Nenkan (The Yearbook of Public Opinion Polls) edited by the Cabinet Public Relations Office for data from 1960 to 2002, and Jiji Seron Chōsa Tokuhō (Monthly Special Report on the Jiji Polls) published by Jiji Press for data from 2003 to 2010.

3. The length of time-series data used in analysis is somewhat arbitrary, but there is little theoretical basis to suspect that this severely harms the validity of the analysis. 


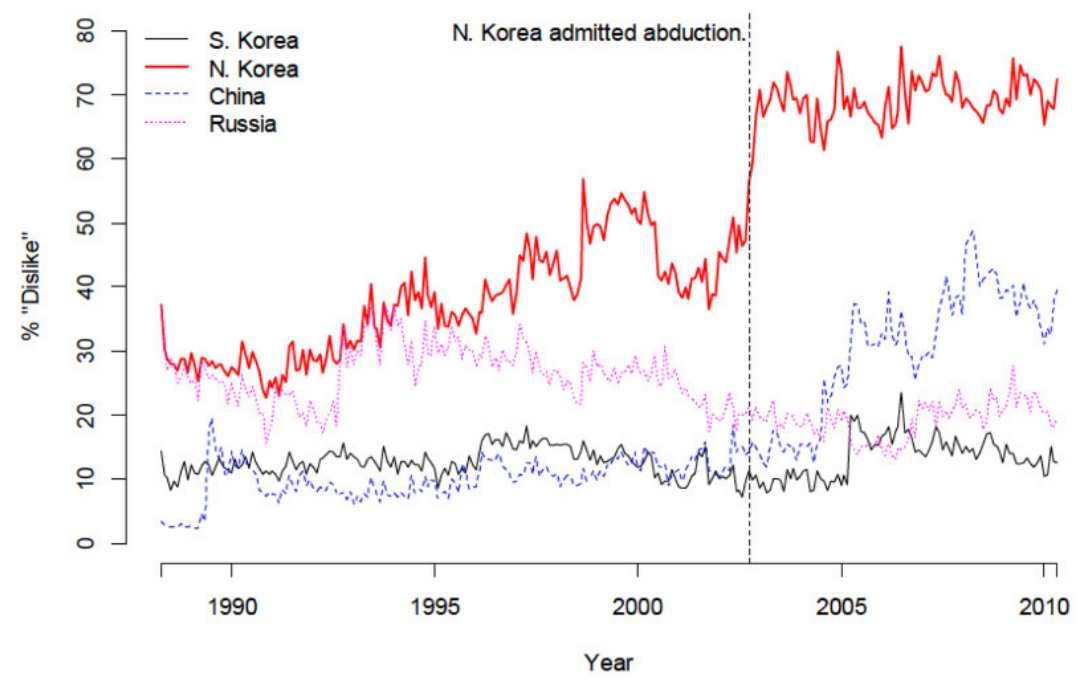

FIGURE 1. Countries Japanese citizens dislike, 1988-2010. Source: The Jiji Polls.

examine the association between Japanese attitudes toward South and North Korea because the media coverage variable is country specific (as discussed later in this paper).

The dependent variables are the percentages of respondents who dislike, rather than like, South Korea and North Korea, because we are interested in the policy constraints of public opinion in Japan. As stated in the previous section, public opinion is supposed to exert influence on policy by constraining the hands of government in policy making. This could be the rationale to focus on public negativity toward a foreign country, as it would be an obstacle for elected officials when taking a compromising stance toward a country.

FIGURE 1 shows the trends in the percentages of respondents who dislike South Korea and North Korea in comparison to those for China and Russia (the Soviet Union to 1991, thereafter Russia). ${ }^{4}$

As seen in FIGURE 1, the percentage of respondents who dislike South Korea fluctuates the least over time, and is the lowest for the four countries on average. In contrast, the percentage of respondents who dislike North Korea is the highest over this time period, and increases each year, particularly after September 2002, when North Korea admitted that

4. The percentages are calculated with a denominator that includes "DK/NA" answers. Also, it must be noted that the total percentage does not equal one hundred because of the multiple-answer format. 
its agents had abducted thirteen Japanese citizens between the late 1970s and the early $198 \mathrm{os}$. Before the early 200os, the percentage of respondents who disliked China was almost constantly around 10 percent. This started rising from the mid-20oos, however, to become the second-highest after North Korea, probably because of the increasing number of Japanese citizens who perceive China as a growing economic and military threat. Finally, in contrast to China, the percentage of respondents who dislike Russia shows a declining trend from around 30 percent in the 1990 os to around 20 percent in the 2000s, which is the second lowest after those for South Korea.

The first key independent variable is the percentage of respondents who dislike the other country in the pair. That is, when the percentage of respondents who dislike South Korea is a dependent variable, that for North Korea serves as an independent variable, and vice versa. The coefficient for this independent variable is interpreted as the degree of association between the two countries, controlling for other variables. ${ }^{5}$

The second key independent variable is the percentage of newspaper articles that feature a country while mentioning the other country in the pair. This variable measures how salient a country is in the media coverage of the other country. For example, the percentage of articles that mention North Korea in which South Korea appears indicates the salience of South Korea in the media coverage of North Korea, which is expected to strengthen the association between Japanese attitudes toward the two countries. Corresponding to Hypothesis 2, if Japanese citizens develop a negative image of North Korea for some reason, then they will also do so for South Korea when they perceive a group identity among the two countries as a result of regularly seeing South Korea in the media coverage on North Korea. The interaction term between the two key independent variables is included in the analysis to test this hypothesis.

With regard to the construction of the variable, first, the number of articles that include “South Korea” (韓国) and “North Korea” (北朝鮮) were respectively counted using the online database of the Yomiuri Shimbun, a private media company with the highest newspaper circulation in Japan. More formal terms such as “Republic of Korea" (大韓民国) and “Democratic People’s Republic of Korea” (朝鮮民主主義人民共和国) were not included in the article count, but they are likely to be a subset of their abbreviations, "South Korea" and "North Korea," in the media reports.

5. We call this "association" rather than "effect" because we have no strong theoretical and statistical basis to claim causality. See also footnote 9. 


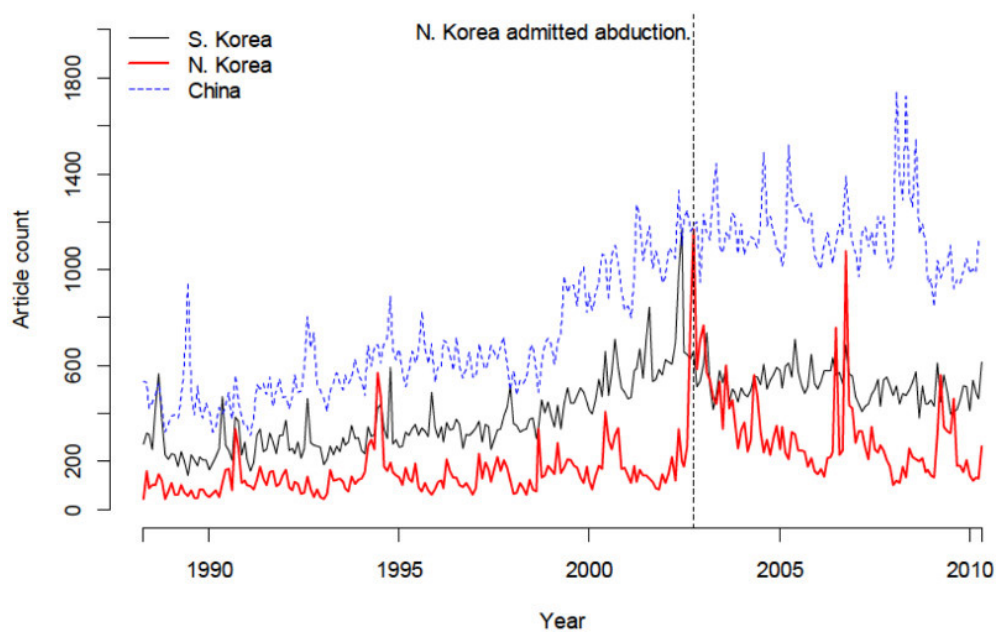

FIGURE 2. The number of articles that mention South Korea, North Korea, and China. Source: The online database of the Yomiuri Shimbun.

The potential problem is that the Yomiuri Shimbun is known for its conservative and pro-government stance. This may harm the generalizability of results-for example, the Yomiuri Shimbun may favor South Korea more than North Korea, but we still believe that the proposed approach is valid to the extent it is concerned with the count, not the content, of articles. That is, we assume that the Yomiuri Shimbun as a newspaper with the highest circulation generally represents the Japanese media, at least in terms of how much they report on South Korean and North Korean issues.

FIGURE 2 illustrates the trends in comparison with the number of articles on China. As seen in this figure, the number of articles that mention South Korea tends to be higher in the 2000 s than in the 199os. While the number of articles mentioning North Korea is the lowest on average over the time period, it jumps sporadically with the occurrence of such events as the admission of abduction in September 2002, as well as the missile launches in May 1993, August 1998, July 2006, and April 2009. Moreover, the number of articles that mention China has been increasing rapidly since the late 1990s, resulting in a widening gap with articles mentioning South Korea.

Second, the percentage of times in which South Korea and North Korea appear in articles that mention the other country in the pair has been calculated. FIgURE 3 illustrates the trends in frequency with which South Korea and China appear in articles that mention North Korea. As seen in this figure, the percentage of times that South Korea appears in articles that 


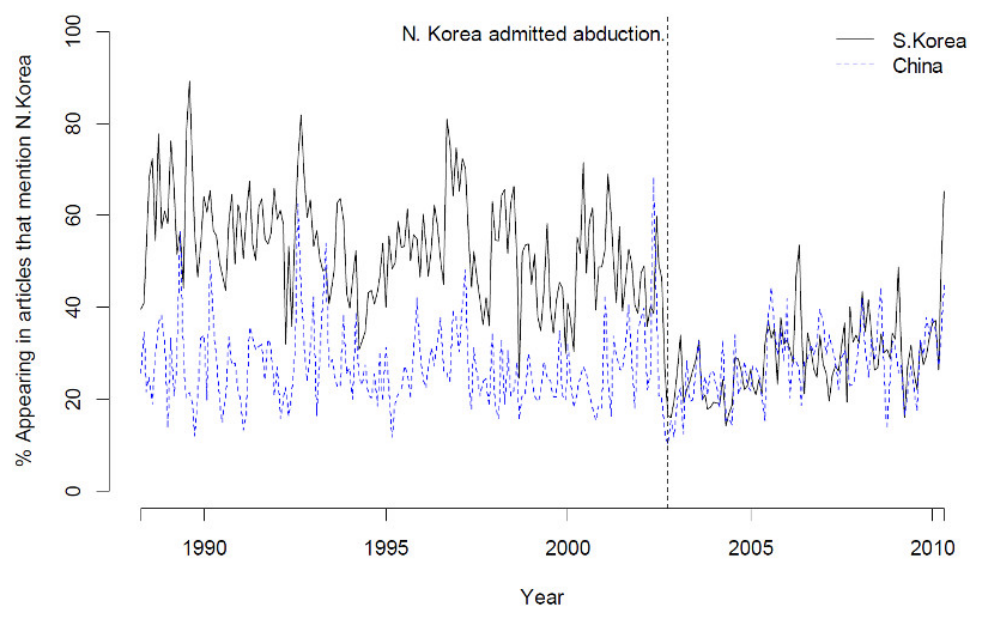

FIGURE 3. Appearances of South Korea and China in articles that mention North Korea.

mention North Korea becomes generally higher than that for China, which suggests that the media relate North Korea to South Korea more often than China. Again, however, the percentage for South Korea is significantly lower after September 2002, when North Korea admitted abducting Japanese citizens. For example, the term "South Korea" is found in 50-60 percent of articles that include the term "North Korea" before news of the abductions broke, and is as low as 30-40 percent thereafter. This means that South Korea appears less frequently in the rapidly increasing number of articles on North Korea following the abduction admission.

FIgURE 4 shows the trends in the frequency with which North Korea and China appear in articles that mention South Korea. While China appears in these articles more often than North Korea, which suggests that the media relate South Korea to China more often than to North Korea, the occurrence of particular events sometimes narrows the gap. Moreover, the trends for North Korea and China show little change, even after the admission of abduction by North Korea.

Other independent variables include the percentage of respondents who dislike China and Russia, event dummies, unemployment rates, ${ }^{6}$ and cabinet approval. ${ }^{7}$ The attitudes toward China are expected to be linked

6. The sources for unemployment rates are: Seron Chōsa Nenkan data from 1960 to 2002, and Jiji Seron Chōsa Tokuhō (see note 2).

7. The source for cabinet approval is the Statistics Bureau, Ministry of Internal Affairs and Communications. 


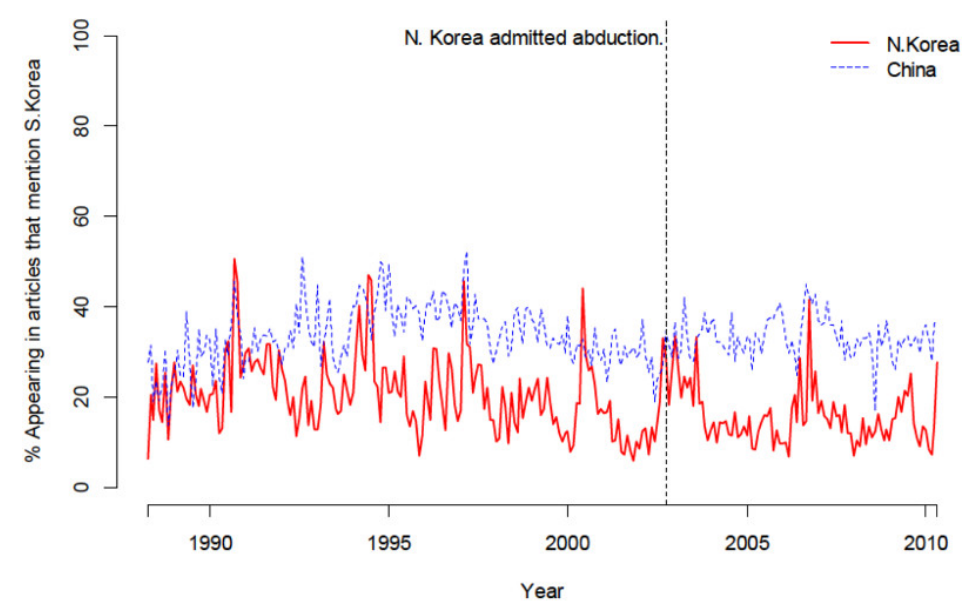

FIGURE 4. Appearances of North Korea and China in articles that mention South Korea.

with those toward both South and North Korea because China joins these two countries in blaming Japan for historical issues, which will make Japanese citizens view China through the same lens as they do South and North Korea. In contrast, the attitudes toward Russia are expected to be associated only with those toward North Korea because these two countries have a shared history as communist states.

Dummy variables were constructed to capture the effects of Korearelated events, including North Korea's missile launches (May 1993, August 1998, July 2006, and April 2009); Kim Jong-il's admission regarding the abduction of Japanese nationals (September 2002); the enactment of Takeshima Day by Shimane Prefecture, Japan (April 2005); and the visits by Japanese prime ministers to Yasukuni Shrine (July 1996, August 2001, April 2002, January 2003, January 2004, October 2005, and August 2006). All the event dummy variables are expected to have a negative impact on Japanese attitudes toward South and North Korea.

Regarding the variable of Takeshima Day, the Shimane Prefectural Assembly designed a commemorative day for the disputed Takeshima Island (Dokdo in Korean) in April 2005, which resulted in aggressive responses from Korean citizens, including the burning of Japanese flags, and increased anti-Korean sentiments among Japanese citizens in turn. Similarly, the visits of Japanese prime ministers to Yasukuni Shrine, where Japanese war criminals are enshrined, regularly raised negative sentiments among Korean citizens, and then among Japanese citizens, due to the Korean reaction. 
Given that governments generally seek to divert public attention from a struggling economy or low approval ratings by promoting hostility against foreign countries (LEVY 1989), high unemployment rates and low cabinet approval are expected to have a negative impact on Japanese attitudes toward South and North Korea.

THE STATISTICAL MODEL

The autoregressive fractionally integrated moving average (ARFIMA) model ${ }^{8}$ was used to analyze the time-series data of Japanese attitudes toward South and North Korea. ARFIMA modeling makes it possible to remove the part of the series that can be explained by itself, and allows a time-series to be fractionally integrated (o $<I<1$ ), while ARIMA modeling requires researchers to decide whether their data were generated by a $I=\mathrm{o}$ (stationary) or $I=1$ (nonstationary, i.e., unit-root) process. In other words, the ARFIMA model is more realistic than the ARIMA model because it does not impose the dichotomy between a stationary and nonstationary time-series.

Both dependent and independent variables are transformed into the white noise residuals of their respective ARFIMA models in order to purge autocorrelation and ensure stationarity before examining the relationship among the series. As the ARFIMA model removes the selfexplanatory part of the time-series, the multivariate model is designed to estimate the instantaneous change in Japanese attitudes toward South and North Korea associated with a change in the independent variables. We seek to detect such instantaneous, rather than persistent, effects because we are interested in explaining the fluctuation, rather than the trends or levels, in Japanese negative sentiments against South and North Korea, in accordance with our theoretical framework. This justifies not using the vector autoregressive (VAR) methodology to analyze the timeseries data.

Moreover, a regression coefficient estimate for the main independent variable in this model is likely to suffer from a bias caused by endogeneity in the sense that the dislikes for North Korea and South Korea influence each other. Therefore, the regression coefficient should be interpreted at best as a partial correlation controlled for other variables, rather than

8. For the political application of Arfima, see Box-StefFensmeier and SMith (1998); Lebo, Walker, and Clarke (2000); Box-Steffensmeier and Tomlison (2000); Clarke and LEBO (2003). 
a causal effect. ${ }^{9}$ The VAR methodology is, however, not necessarily helpful, because increases in the percentages of respondents who dislike South Korea and North Korea are most likely to be simultaneous in the actual observation of the monthly polls, even if they are theoretically sequential. ${ }^{10}$

The descriptive statistics of variables included in the model are provided in TABLE 1. Because of the nature of our approach, the variables can take negative values after being transformed into white noise residuals, even if they originally represent positive percentage values. Nevertheless, the "whitened" values still maintain the original scale as percentage points.

\section{Results}

TABLE 2 provides the statistical results of the analysis of Japanese negative attitudes toward South Korea. Consistent with Hypothesis 1, Model 1 (TABLE 2) shows that the percentage of respondents who dislike North Korea has a statistically significant positive association with that for South Korea. More substantively, a point increase in the former is associated with a 0.188 point estimated increase in the latter (with the $95 \%$ CI of [0.121, $0.255])$.

9. Partial correlation is directly linked to multiple linear regression coefficient with the same $p$-value, for example, as noted below.

$$
\begin{aligned}
& r_{y x_{1}}, x_{2}=\frac{r_{y x_{1}}-r_{y x_{2}}{ }^{r} x_{1} x_{2}}{\sqrt{\left(1-r_{y x_{2}}^{2}\right)\left(1-r_{x_{1} x_{2}}^{2}\right)}} \\
& \beta_{x_{1}}=\frac{r_{y x_{1}}-r_{y x_{2}} r_{x_{1} x_{2}}}{1-r_{x_{1} x_{2}}^{2}}
\end{aligned}
$$

The ARFIMA filtering technique is used to make sure that the multiple liner regression model is consistent with the Gauss-Markov assumptions, especially no autocorrelation, and to examine an instantaneous change.

10. Note that VAR modeling relies on the notion of Granger causality to address endogeneity, but, as is well known, time precedence does not guarantee causality. In particular, in the data analyzed in this study, even if an increase in the dislike for North Korea is found to lead to an increase in the dislike for South Korea next month, it does not necessarily mean that the former causes the latter (and vice versa). Also, a month time lag seems to be substantively too long. For example, it is not intuitive to consider that people who got angry with North Korea this month were driven to hate South Korea next month. 
TABLE 1. Descriptive Statistics.

\begin{tabular}{|c|c|c|c|c|c|}
\hline & $\mathrm{N}$ & MIN. & MAX. & MEAN & $\begin{array}{l}\text { ST. } \\
\text { DEV. }\end{array}$ \\
\hline \% Dislike S. Korea & $\begin{array}{c}266 \\
(265)\end{array}$ & $\begin{array}{c}7.10 \\
(-4.70)\end{array}$ & $\begin{array}{l}23.60 \\
(10.45)\end{array}$ & $\begin{array}{l}12.87 \\
(.03)\end{array}$ & $\begin{array}{c}2.61 \\
(1.59)\end{array}$ \\
\hline \% Dislike N. Korea & $\begin{array}{c}266 \\
(265)\end{array}$ & $\begin{array}{c}22.60 \\
(-8.63)\end{array}$ & $\begin{array}{c}77.50 \\
(16.64)\end{array}$ & $\begin{array}{l}48.33 \\
(.24)\end{array}$ & $\begin{array}{l}16.66 \\
(3.20)\end{array}$ \\
\hline$\%$ Dislike China & $\begin{array}{c}266 \\
(265)\end{array}$ & $\begin{array}{c}2.20 \\
(-5.33)\end{array}$ & $\begin{array}{l}48.70 \\
(13.81)\end{array}$ & $\begin{array}{l}16.92 \\
(.24)\end{array}$ & $\begin{array}{l}11.52 \\
(2.32)\end{array}$ \\
\hline \% Dislike Russia & $\begin{array}{c}266 \\
(265)\end{array}$ & $\begin{array}{l}13.00 \\
(-6.39)\end{array}$ & $\begin{array}{l}36.90 \\
(9.19)\end{array}$ & $\begin{array}{l}23.86 \\
(-.18)\end{array}$ & $\begin{array}{l}5.26 \\
(2.35)\end{array}$ \\
\hline $\begin{array}{l}\text { Missile launch by N. } \\
\text { Korea }\end{array}$ & 266 & $\mathrm{O}$ & 1 & .01 & .11 \\
\hline $\begin{array}{l}\text { Abduction admission } \\
\text { by N. Korea }\end{array}$ & 266 & $\mathrm{O}$ & 1 & .00 & .06 \\
\hline $\begin{array}{l}\text { Enactment of } \\
\text { Takeshima Day }\end{array}$ & 266 & $\mathrm{O}$ & 1 & .00 & .06 \\
\hline Visit Yasukuni Shrine & 266 & $\mathrm{O}$ & 1 & .03 & .16 \\
\hline $\begin{array}{l}\% \text { S. Korea appearing } \\
\text { in articles that men- } \\
\text { tion N. Korea }\end{array}$ & $\begin{array}{c}266 \\
(265)\end{array}$ & $\begin{array}{c}14.06 \\
(-28.83)\end{array}$ & $\begin{array}{l}89.36 \\
(31.81)\end{array}$ & $\begin{array}{l}44.52 \\
(-.65)\end{array}$ & $\begin{array}{l}15.62 \\
(9.46)\end{array}$ \\
\hline $\begin{array}{l}\% \mathrm{~N} . \text { Korea appearing } \\
\text { in articles that men- } \\
\text { tion S. Korea }\end{array}$ & $\begin{array}{c}266 \\
(265)\end{array}$ & $\begin{array}{c}5.84 \\
(-12.96)\end{array}$ & $\begin{array}{l}50.65 \\
(30.38)\end{array}$ & $\begin{array}{l}18.84 \\
(-.14)\end{array}$ & $\begin{array}{c}8.03 \\
(6.59)\end{array}$ \\
\hline \% Unemployment & $\begin{array}{c}266 \\
(265)\end{array}$ & $\begin{array}{l}2.00 \\
(-.33)\end{array}$ & $\begin{array}{l}5.60 \\
(.39)\end{array}$ & $\begin{array}{l}3.75 \\
(.01)\end{array}$ & $\begin{array}{l}1.11 \\
(.11)\end{array}$ \\
\hline \% Cabinet Approval & $\begin{array}{c}266 \\
(265) \\
\end{array}$ & $\begin{array}{c}4.40 \\
(-36.21) \\
\end{array}$ & $\begin{array}{l}78.40 \\
(58.19)\end{array}$ & $\begin{array}{l}37.35 \\
(.12)\end{array}$ & $\begin{array}{l}12.98 \\
(8.15)\end{array}$ \\
\hline
\end{tabular}

Note: In the analysis, variables are transformed into the white noise residuals of their respective ARFIMA models in order to purge autocorrelation and ensure stationarity. The "whitened" values of the variables are in parentheses. 
The percentage of respondents who dislike China also has a statistically significant positive association with that for South Korea, leading to a 0.113 point estimated increase in the latter (with the 95\% CI of [0.046, 0.180]). In contrast, the percentage of respondents who dislike Russia has no statistically significant association with that for South Korea.

Among the event dummy variables, only the enactment of Takeshima Day has a statistically significant positive impact, which is estimated to increase the percentage of respondents who dislike South Korea by 10.433 points (with the 95\% CI of [7.901, 12.965]).

Consistent with Hypothesis 2, Model 2 (TABLE 2) shows that the interaction term between the percentage of respondents who dislike North Korea and the percentage of times in which South Korea appeared in articles that mention North Korea is statistically significant positive. This suggests that negative Japanese attitudes toward North Korea are more strongly associated with those toward South Korea, as South Korea appears more frequently in the media reports on North Korea.

More substantively, the coefficient with the percentage of respondents who dislike North Korea can be arranged as a linear function of the percentage of South Korea appearing in articles that mention North Korea, as follows:

$0.205+0.007 \mathrm{x} \%$ S. Korea appearing in articles that mention N. Korea

Inserting realistic values for a change in the percentage of South Korea appearing in articles that mention North Korea into the aforementioned formula, ${ }^{11}$ FIGURE 5 provides a graphic interpretation of the impact of the percentage of respondents who dislike North Korea on the percentage of respondents who dislike South Korea.

As seen in FIGURE 5, when the percentage of times in which South Korea appears in articles that mention North Korea decreases by ten points, a point increase in the percentage of respondents who dislike North Korea is estimated to be associated with a 0.133 point increase in those who dislike South Korea (with the 95\% CI of [0.055, 0.211]). Meanwhile, when it increases by ten points, a point increase in the former is estimated to lead to a 0.278 point increase in the latter (with the 95\% CI of [0.182, 0.374]). Although statistically significant positive in either case, the media coverage

11. According to TABLE 1, minimum value, maximum value, and standard deviation for a "whitened" time-series of the percentage of South Korea appearing in articles that mention North Korea, which represent a monthly percentage point change in the article count unexplained by its past values, are -28.83, 31.81, and 9.46, respectively. Based on these statistics, we consider a percentage-point change ranging from -10 to +10 "realistic." 
16 | JAPANESE POlitiCAL SCIENCE REVIEW 4 (2018)

TABLE 2. The correlation of negative Japanese attitudes toward South Korea.

\begin{tabular}{|c|c|c|}
\hline & MODEL 1 & MODEL 2 \\
\hline Constant & $\begin{array}{l}-.077 \\
(.080)\end{array}$ & $\begin{array}{l}-.051 \\
(.080)\end{array}$ \\
\hline \% Dislike N. Korea & $\begin{array}{l}.188^{\star *} \\
(.034)\end{array}$ & $\begin{array}{l}.205^{* *} \\
(.034)\end{array}$ \\
\hline \% Dislike China & $\begin{array}{l}.113^{* *} \\
(.037)\end{array}$ & $\begin{array}{l}.111^{\star *} \\
(.036)\end{array}$ \\
\hline \% Dislike Russia & $\begin{array}{l}-.010 \\
(.040)\end{array}$ & $\begin{array}{l}-.020 \\
(.039)\end{array}$ \\
\hline $\begin{array}{l}\text { Missile launch by N. } \\
\text { Korea }\end{array}$ & $\begin{array}{l}.025 \\
(.807)\end{array}$ & $\begin{array}{l}1.802 \\
(1.061)\end{array}$ \\
\hline $\begin{array}{l}\text { Abduction admission by } \\
\text { N. Korea }\end{array}$ & $\begin{array}{c}-.252 \\
(1.298)\end{array}$ & $\begin{array}{c}.952 \\
(1.369)\end{array}$ \\
\hline $\begin{array}{l}\text { Enactment of Takeshima } \\
\text { Day }\end{array}$ & $\begin{array}{c}10.433^{\star *} \\
(1.292)\end{array}$ & $\begin{array}{l}10.444^{* *} \\
(1.279)\end{array}$ \\
\hline Visit Yasukuni Shrine & $\begin{array}{l}-.444 \\
(.484)\end{array}$ & $\begin{array}{l}-.446 \\
(.479)\end{array}$ \\
\hline $\begin{array}{l}\% \mathrm{~S} . \text { Korea appearing in } \\
\text { articles that mention } \mathrm{N} \text {. } \\
\text { Korea }\end{array}$ & $\begin{array}{l}-.013 \\
(.009)\end{array}$ & $\begin{array}{l}-.012 \\
(.009)\end{array}$ \\
\hline $\begin{array}{l}\% \text { Dislike N. Korea } \times \% \\
\text { S. Korea appearing in } \\
\text { articles that mention N. } \\
\text { Korea }\end{array}$ & & $\begin{array}{l}.007^{*} \\
(.003)\end{array}$ \\
\hline$\%$ Unemployment & $\begin{array}{l}-.529 \\
(.723)\end{array}$ & $\begin{array}{l}-.704 \\
(.719)\end{array}$ \\
\hline \% Cabinet Approval & $\begin{array}{l}-.003 \\
(.010)\end{array}$ & $\begin{array}{l}-.002 \\
(.010)\end{array}$ \\
\hline $\mathrm{n}$ & 265 & 265 \\
\hline Adj.- $\mathrm{R}^{2}$ & .373 & .386 \\
\hline
\end{tabular}

${ }^{* *} p<.01,{ }^{*} p<.05, \dagger p<.10$

Standard errors are in parentheses. 


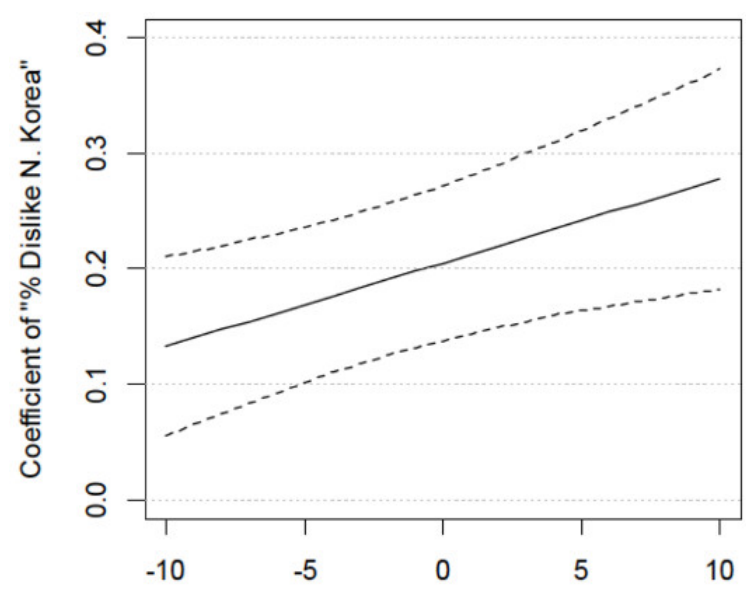

Change in "\% S. Korea appearing in articles that mention N. Korea"

FIGURE 5. The coefficient of "\% Dislike N. Korea."

Note: The dotted lines are the upper and lower limits of the $95 \%$ confidence interval.

makes a substantial difference to the degree to which Japanese attitudes toward North Korea are associated with those toward South Korea. ${ }^{12}$

TABLE 3 provides the statistical results of the analysis of negative Japanese attitudes toward North Korea. Consistent with Hypothesis 1, Model 1 (TABLE 3) indicates that the percentage of respondents who dislike South Korea has a statistically significant positive association with the percentage who dislike North Korea. More substantively, a point increase in the former is estimated to lead to a 0.618 point increase in the latter (with the $95 \%$ CI of $[0.414,0.818])$.

Moreover, the percentage of respondents who dislike China and Russia have a statistically significant positive association with the percentage who dislike North Korea, respectively. A point increase in that for China is estimated to lead to a 0.267 point increase in the latter (with the $95 \%$ CI of [0.144, 0.390]), while a point increase in that for Russia is estimated to lead to a 0.519 point increase in the latter (with the $95 \%$ CI of [0.399, 0.639]). This suggests that Japanese citizens see the two countries and North Korea through the same lens.

12. Although the 95 percent confidence intervals for the two illustrative estimates overlap, this does not necessarily indicate that there is no significant difference between these estimates. To know if they are significantly different, we need to calculate the 95 percent confidence interval for the difference between the estimates and see if it includes $\mathrm{o}$. 
TABLE 3. The correlation of negative Japanese attitudes toward North Korea.

\begin{tabular}{|c|c|c|}
\hline & MODEL 1 & MODEL 2 \\
\hline Constant & $\begin{array}{l}.169 \\
(.139)\end{array}$ & $\begin{array}{c}.167 \\
(.140)\end{array}$ \\
\hline \% Dislike S. Korea & $\begin{array}{l}.616^{* *} \\
(.103)\end{array}$ & $\begin{array}{l}.618^{\star *} \\
(.103)\end{array}$ \\
\hline \% Dislike China & $\begin{array}{l}.267^{* *} \\
(.063)\end{array}$ & $\begin{array}{l}.266^{* *} \\
(.063)\end{array}$ \\
\hline \% Dislike Russia & $\begin{array}{l}.519^{\star *} \\
(.061)\end{array}$ & $\begin{array}{l}.519^{\star *} \\
(.061)\end{array}$ \\
\hline $\begin{array}{l}\text { Missile launch by N. } \\
\text { Korea }\end{array}$ & $\begin{array}{l}6.933^{* *} \\
(1.324)\end{array}$ & $\begin{array}{l}7.015^{* *} \\
(1.395)\end{array}$ \\
\hline $\begin{array}{l}\text { Abduction admission by } \\
\text { N. Korea }\end{array}$ & $\begin{array}{l}7.054^{\star *} \\
(2.212)\end{array}$ & $\begin{array}{l}7.078^{* *} \\
(2.220)\end{array}$ \\
\hline $\begin{array}{l}\text { Enactment of Takeshima } \\
\text { Day }\end{array}$ & $\begin{array}{l}-9.567^{* *} \\
(2.454)\end{array}$ & $\begin{array}{l}-9.691^{* *} \\
(2.543)\end{array}$ \\
\hline $\begin{array}{l}\text { Visit to the Yasukuni } \\
\text { Shrine }\end{array}$ & $\begin{array}{l}1.085 \\
(.844)\end{array}$ & $\begin{array}{l}1.086 \\
(.846)\end{array}$ \\
\hline $\begin{array}{l}\% \mathrm{~N} . \text { Korea appearing in } \\
\text { articles that mention S. } \\
\text { Korea }\end{array}$ & $\begin{array}{l}.042^{*} \\
(.021)\end{array}$ & $\begin{array}{l}.042^{*} \\
(.021)\end{array}$ \\
\hline $\begin{array}{l}\% \text { Dislike S. Korea } \times \% \\
\text { N. Korea appearing in } \\
\text { articles that mention S. } \\
\text { Korea }\end{array}$ & & $\begin{array}{l}-.002 \\
(.012)\end{array}$ \\
\hline \% Unemployment & $\begin{array}{l}-1.365 \\
(1.262)\end{array}$ & $\begin{array}{l}-1.377 \\
(1.266)\end{array}$ \\
\hline$\%$ Cabinet Support & $\begin{array}{l}.030 \dagger \\
(.017)\end{array}$ & $\begin{array}{l}.030 \dagger \\
(.017)\end{array}$ \\
\hline $\mathrm{n}$ & 265 & 265 \\
\hline Adj.- $\mathrm{R}^{2}$ & .531 & .529 \\
\hline
\end{tabular}


The missile launch and the admission of abduction by North Korea have a statistically significant positive impact on the percentage of respondents who dislike North Korea, and are estimated to lead to a 6.933 point increase (with the $95 \% \mathrm{CI}$ of $[4.338,9.528]$ ) and a 7.054 point increase (with the $95 \%$ CI of $[2.718,11.390])$, respectively. Meanwhile, the enactment of Takeshima Day also has a statistically significant negative impact on the percentage of respondents who dislike North Korea, and is estimated to lead to a 9.567 decrease (with the $95 \%$ CI of $[-14.377,-4.757]$ ). A possible reason for this is that conflict between Japan and South Korea eases Japanese hostility toward North Korea.

Contrary to Hypothesis 2, Model 2 (TABLE 3) indicates that the interaction term between the percentage of respondents who dislike South Korea and the percentage of times in which North Korea appears in articles that mention South Korea is not statistically significant. This suggests that the frequency with which North Korea appears in media reports on South Korea does not affect the degree to which negative Japanese attitudes toward South Korea are associated with those toward North Korea. FIGURE 6 visualizes the insignificant interaction effect of the article count with the dislike for South Korea in the same manner as in FIGURE 5, which shows that the coefficient with the dislike for South Korea is almost constant (and significant), regardless of the values of the article count.

A possible reason for the null result is that the trend in the frequency with which North Korea appears in the articles that mention South Korea shows little change, even after the admission of abduction by North Korea in September 2002, as shown in FIGURE 4. While South Korea appeared less frequently in articles on North Korea after the admission (see FIGURE 3), North Korea was referred to in the articles on South Korea at almost the same level even after the event. Such a minor change in the way the media treat North Korea in terms of article count may explain its insignificant effect on the association between South Korea and North Korea in the public mind, although the explanation for such a small change in perception remains unclear.

\section{Illustrative Examples: North Korean Missile-Launching}

In order to help interpret the interaction between the article count and the attitudes toward South Korea, we will briefly look at two cases of North Korean missile launches in 1998 and 2009.

For the missile launch on August 31, 1998, an increase in the percentage of respondents who dislike North Korea seemed to be associated with an increase in the percentage of those who disliked South Korea, while South 


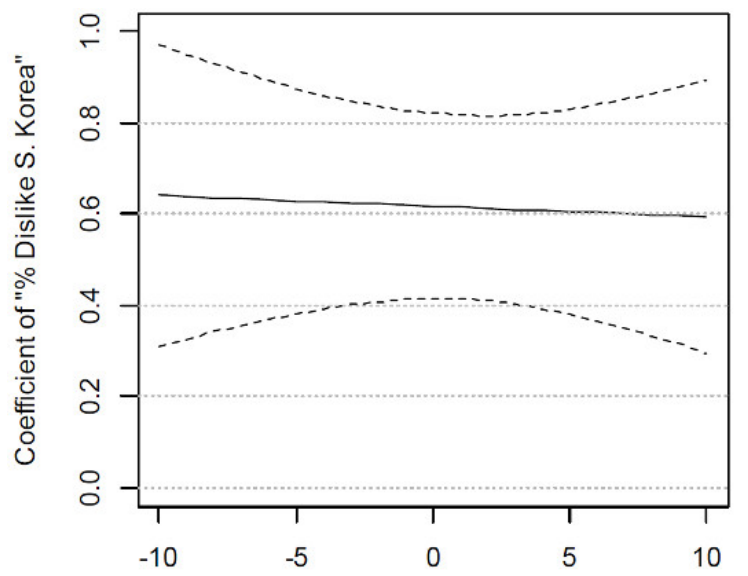

Change in "\% N. Korea appearing in articles that mention S. Korea"

FIGURE 6. The coefficient of "\% Dislike S. Korea."

Note: The dotted lines are the upper and lower limits of the $95 \%$ confidence interval.

Korea frequently appeared in articles that mention North Korea. In contrast, in the case of the missile launch on April 5, 2009, an increase in the percentage of respondents who disliked North Korea seemed to be hardly associated with an increase in the percentage of those who disliked South Korea, while South Korea did not appear very frequently in articles that mention North Korea.

\section{THE MISSILE LAUNCH ON AUGUST 31, 1998}

On August 31, 1998, a two-stage intermediate-range ballistic missile (Taepodong-1) was fired over Japanese territory and landed in the Pacific Ocean. Occurring without any advance notice, this missile launch surprised Japanese citizens and generated a very negative public opinion toward North Korea.

The percentage of respondents who disliked North Korea increased from 41.3 to 56.9 percent, while that for South Korea increased from 14.3 to 15.9 percent in the same time period. In the year before the missile launch, the average percentage of times in which South Korea appeared in articles mentioning North Korea was 53.2, which indicates that South Korea appeared in more than the half of the articles that mention North Korea.

Indeed, during this time, the tone of the articles in the Yomiuri Shimbun generally exhibited the mood of reconciliation between South and North Korea, as seen in the following article headlines (translated by the author). 
- "Resuming the dialog between South and North Korea emphasized: President Kim Daejung addressed the memorial ceremony of the independence movement" (March 2, 1998).

- "North Korea looks forward to economic cooperation: Exiled former Secretary Hwang's view" (June 16, 1998).

- "Cooperation should be maintained despite the capture of North Korean submarine, says President Kim Daejung” (June 25, 1998).

These newspaper articles might have encouraged the perception of Japanese citizens that North Korea belonged to the same group as South Korea, thus strengthening the convergence of Japanese attitudes toward South Korea and North Korea.

THE MISSILE LAUNCH ON APRIL 5, 2009

Anticipated a few days in advance, Taepodong-2 was fired over Japanese territory and landed in the Sea of Japan (the East Sea of Korea) on April 5, 2009. This resulted in public opinion being overwhelmingly anti-North Korean, and the Japanese government strongly condemned the missile launch.

The percentage of respondents who disliked North Korea increased from 68.1 to 75.8 percent, while that for South Korea remained at 14 percent. In the year before the missile launch, the average percentage of times in which South Korea appeared in articles mentioning North Korea was $33.2 \%$, which shows that South Korea appeared in just a third of articles mentioning North Korea.

In the year prior to this launch, the tone of the articles in the Yomiuri Shimbun generally emphasized the eccentricity of North Korea as distinguishing it from South Korea, as seen in the following article headlines.

- "North Korea arrested journalists" (March 20, 2009).

- "Weapons exports from North Korea increase in 2008" (January 13, 2009).

Moreover, even when South Korea appeared in an article on North Korea, they typically reported the antagonism between the two countries, as seen in the following headline.

- "South Korean President Lee accepts the interception of missiles" (March 30, 2009).

These newspaper articles might have reduced the perception of Japanese citizens of North Korea belonging to the same group as South Korea, thus weakening the association between these two countries in Japanese attitudes toward South Korea and North Korea. 


\section{Conclusion}

This study has examined the effect of media coverage on the public perception of the association between two countries, arguing that as the media relate two countries more frequently in their coverage, public attitudes toward these countries become more strongly associated with each other. Consistent with this theory, a time-series analysis of monthly public opinion data from 1988 to 2010 found that negative Japanese attitudes toward North Korea were more strongly associated with those toward South Korea when South Korea appeared in newspaper articles that mention North Korea more frequently. This suggests that the media plays a significant role in influencing the extent to which citizens group countries together.

The argument presented in this study can be elaborated upon through additional analyses. First, as the illustrative cases in this study strongly suggest, it is important to test the impact of content in newspaper articles that relate South Korea and North Korea. The media coverage variable in this study only measures how often a relationship between the two countries is reported, but the tone of these articles regarding the relationship between North and South Korea should be also coded as quantitative data by using text-mining techniques.

Second, the source for the media coverage variable should include a much wider variety of mass media. This study only uses the Yomiuri Shimbun, a relatively conservative, pro-government newspaper company in Japan, in the construction of the variable. Other newspapers that may exert an influence on public opinion also need to be considered as alternative data sources, especially when we are interested in the impact of content. Also, television media, as well as the internet, may be promising sources of data for future research.

Third, as mentioned already, the statistical model used in this study obviously suffers from endogeneity. Public attitudes toward South Korea and North Korea are likely to influence each other, but it is difficult to separate them even with the VAR modeling approach, because of theoretically assumed instantaneous reactions of citizens to events and the nature of the monthly data. Therefore, it is desirable to examine daily or even hourly data collected through online surveys to test the hypotheses more rigorously.

Finally, it is important to test the hypotheses using data for countries other than Japan for generalization. Indeed, the hypothesis regarding the effect of the media coverage on the convergence of public attitudes toward foreign countries has a broader scope that extends well beyond the Japanese and East Asian context. 


\section{RefERENCES}

Anderson, John R.

1983 The Architecture of Cognition. Cambridge, MA: Harvard University Press.

Baum, Matthew A., and Philip B. K. Potter

2015 War and Democratic Constraint: How the Public Influences Foreign Policy. Princeton, NJ: Princeton University Press.

Box-Steffensmeier, Janet M., and Renee M. Smith

1998 "Investigating Political Dynamics Using Fractional Integration Methods.” American Journal of Political Science 42: 661-89.

Box-Steffensmeier, Janet M., and Andrew R. Tomlison

2000 "Fractional Integration Methods in Political Science." Electoral Studies 19: $63-76$.

Chandler, Charles R., and Yung-mei Tsai

2001 "Social Factors Influencing Immigration Attitudes: An Analysis of Data from the General Social Survey" The Social Science Journal 38: 177-88.

Clarke, Harold D., and Matthew J. Lebo

2003 "Fractional (Co) integration and Governing Party Support in Britain." British Journal of Political Science 33: 283-301.

Dell'orto, Giovanna, Dong Dong, Adina Schneeweis, and Jensen Moore

2004 “The Impact of Framing on Perception of Foreign Countries." Ecquid Novi: African Journalism Studies 25: 294-312.

Fukumoto Kentaro and Hiroya Furuta

2012 "Kinrin Shokoku no Suki Kirai ni Shinbun Hōdō ga Ataeru Eikyō" (How Newspaper Reports Affect How Much Japanese Like/Dislike Their Neighboring Countries). Toyo Bunka Kenkyū (Journal of Asian Cultures) 14: 243-65.

Furia, Peter A., and Russell E. LuCAS

2006 "Determinants of Arab Public Opinion on Foreign Relations." International Studies Quarterly 50: 585-605.

Glazier, Rebecca. A., and Amber. E. Boydstun

2012 "The President, the Press, and the War: A Tale of Two Framing Agendas." Political Communication 29: 428-46.

Goldsmith, Benjamin E., and Yusaku Horiuchi

2012 "In Search of Soft Power: Does Foreign Public Opinion Matter for US Foreign Policy?” World Politics 64: 555-85.

Hainmueller, Jens, and Michael J. Hiscox

2007 "Educated Preferences: Explaining Attitudes toward Immigration in Europe." International Organization 61: 399-442. 
Hartley, Thomas, and Bruce RussetT

1992 "Public Opinion and the Common Defense: Who Governs Military Spending in the United States?" American Political Science Review 86: 905-15.

Hayes, Danny, and Matt Guardino

2012 Influence from Abroad: Foreign Voices, the Media, and U.S. Public Opinion. New York, NY: Cambridge University Press.

Huntington, Samuel

1993 “The Clash of Civilizations?” Foreign Affairs 72: 22-50.

IzUMIKAWA, Yasuhiro

2010 "Explaining Japanese Antimilitarism: Normative and Realist Constraints on Japan's Security Policy." International Security 35: 123-60.

JACoBs, Lawrence R., and Benjamin I. PAGE

2005 "Who Influences U.S. Foreign Policy?" American Political Science Review 99: 107-23.

Lebo, Matthew J., Robert W. Walker, and Harold D. Clarke

2000 "You Must Remember This: Dealing with Long Memory in Political Analysis." Electoral Studies 19: 31-48.

LEVY, Jack

1989 “The Diversionary Theory of War: A Critique." In Handbook of War Studies, ed. M. I. Midlarsky, 259-88. London: Unwin-Hyman.

Lodge, Milton, and Kathleen M. McGraw

1991 "Where is the Schema? Critiques." American Political Science Review 85: 1357-64.

McLaren, Lauren M.

2003 "Anti-Immigrant Prejudice in Europe: Contact, Threat Perception, and Preferences for the Exclusion of Migrants." Social Forces 81: 909-36.

McQuaIL, Denis

2010 McQuail's Mass Communication Theory. 6th ed. Thousand Oaks, CA: Sage.

MeArsheimer, John

1990 “Back to the Future." International Security 15: 5-56.

MIYAKe Ichiro

2001 "Taigaikoku Taido ni okeru Reisen Kōzō to Sono Henyō" (The Cold War Structure and its Change in Voters' Attitudes toward Foreign Countries). In 55-nen Taiseika no Seiji to Keizai (Politics and Economics During the 1955 Party System), I. Miyake, Y. Nishizawa, and M. Kohno, eds., 59-89. Tokyo: Bokutakusha.

Perry, David K.

1987 “The Image Gap: How International News Affects Perceptions of Nations." Journalism \& Mass Communication Quarterly 64: 416-33. 
1990 "News Reading, Knowledge About, and Attitudes toward Foreign Countries." Journalism \& Mass Communication Quarterly 67: 353-58.

Putnam, Robert D.

1988 "Diplomacy and Domestic Politics: The Logic of Two-Level Games." International Organization 42: 427-60.

Russett, Bruce, and John OneaL

2001 Triangulating Peace. New York: Norton.

SAlA, Brian R., John T. ScotT, and James F. SpRIGgs II

2007 "The Cold War on Ice: Constructivism and the Politics of Olympic Figure Skating Judging." Perspectives on Politics 5: 17-29.

WALLERSTEIN, Immanuel

2002 “The Eagle Has Crash-Landed.” Foreign Policy 131: 60-68. 